\title{
The Shakespearean contribution to neuroimmunology: the Ophelia syndrome
}

\author{
Sergio A. Castillo-Torres, Carlos A. Soto-Rincón and Ingrid Estrada-Bellmann \\ Universidad Autónoma de Nuevo León, Hospital Universitario "Dr. José Eleuterio González", Servicio de Neurología, Nuevo León, Mexico
}

Dear editor:

With great interest we read the article by LópezValdés et al. about the neuropsychiatric allusions in Shakespeare's work. ${ }^{1}$ The landscape offered by the authors undoubtedly invites to delve into the Bard's work, in a clinical-literary analysis; thus we agree we agree with them in the "Renaissance neurologist" denomination. The authors skillfully point out the neurological references present in Hamlet: his depression and psychopathy, and "juvenile female madness" in Ophelia.

However, we noticed the omission of one of Shakespeare's most celebrated neuropsychiatric allusions: the Ophelia syndrome,$^{2}$ memory loss (paraneoplastic limbic encephalitis) secondary to Hodgkin's disease. In addition to coining the eponym (after observing the symptoms in his own daughter), lan Carr prefigured neuronal autoantibodies at least four years before they were associated with the disease., Why Ophelia? We must remember that Ophelia -in Hamlet-, "divided from herself and her fair judgment", ${ }^{5}$ drowns herself in the brook, after the death of Polonius -her father- at the hands of
Hamlet, a circumstance that she herself brought on by rejecting him, ironically, by orders of Polonius himself. In the description of the syndrome, the patient defeats lymphoma and survives, recovering her memory. Although the outcomes diverge, something in common underlies: in both cases, the patients, "unaware of their own misfortune", set in motion the mechanisms that lead, in one to amnesia and in the other to death, thus maintaining the appropriateness of the eponymous and the prestige of the "Renaissance neurologist".

\section{References}

1. López-Valdés JC, Miranda-Hernández A, Medina-Medina JA. Implicaciones psiquiátricas y neurológicas en la literatura shakespeariana. Breve analisis. Gac Med Mex. 2018;154:613-616.

2. Carr I. The Ophelia syndrome: memory loss in Hodgkin's disease. Lancet. 1982;1:844-845.

3. Dhib-Jalbut S, Liwnicz BH. Immunocytochemical binding of serum IgG from a patient with oat cell tumor and paraneoplastic motoneuron disease to normal human cerebral cortex and molecular layer of the cerebellum. Acta Neuropathol. 1986;69:96-102.

4. Bakheit AM, Kennedy PG, Behan PO. Paraneoplastic limbic encephalitis: clinico-pathological correlations. J Neurol Neurosurg Psychiatry. 1990;53: 1084-1088.

5. Shakespeare W. Hamlet, príncipe de Dinamarca. En: Astrana-Marín L, editor. Obras Completas. Madrid: Aguilar; 1947.
Gac Med Mex. 2019;155:102-102

Contents available at PubMed www.gacetamedicademexico.com 